\title{
Analisis Strategi Bisnis Roti Pada Nadhira Napoleon Pekanbaru
}

\author{
Dwita Febrianti ${ }^{1}$, Lesty Rahmadani ${ }^{2}$, Sari Ramadhani ${ }^{3}$, Sella Azara Lailatul Hidayah4 ${ }^{4}$ \\ Dian Puji Puspita Sari ${ }^{5}$ \\ ${ }^{12345}$ Program Studi Akuntansi, Fakultas Ekonomi dan Bisnis, Universitas Muhammadiyah \\ Riau \\ E-mail: 180301056@student.mri.ac.id
}

\begin{abstract}
Abstrak
Saat ini perkembangan bisnis di Indonesia di isi dengan bisnis kreatif, salah satunya di bidang kuliner. Bisnis tersebut tidak terlepas dari persaingan ketat dan besar bagi para usahawan khususnya di bidang kuliner roti. Penelitian ini bertujuan untuk mendeskripsikan bagaimana penerapan strategi bisnis roti Nadhira Napoleon Pekanbaru. Metode yang digunakan adalah metode kualitatif deskriptif dengan cara menggunakan penelitian diskusi. Analisis SWOT digunakan dalam penelitian ini untuk mendeskripsikan dan memilih strategi yang tepat untuk mempertahankan eksistensi usaha, Dalam praktiknya, berbisnis kuliner membutuhkan strategi yang tepat agar mampu bersaing dengan bisnis sejenisnya. Hasil penelitian ini menunjukkan bahwa Nadhira Napoleon Pekanbaru memiliki sejumlah strategi bisnis yang tepat untuk meningkatkan penjualan dan mengatasi persaingan tersebut. Faktor utama dari upaya tersebut adalah dengan melakukan promosi menggunakan media sosial maupun secara langsung dengan cara yang kreatif dan inovatif untuk menarik perhatian para pelanggan dan konsumen baru, hal tersebut dilakukan demi memperkenalkan dan memperkuat brand usaha roti Nadhira Napoleon Pekanbaru.
\end{abstract}

Kata Kunci : Strategi bisnis, Analisis SWOT, Persaingan.

\begin{abstract}
Business development in Indonesia is currently filled with creative businesses, one of which is in the culinary field. The business is inseparable from the fierce and big competition for entrepreneurs in the culinary field of bread in particular. This study aims to describe how the implementation of Nadhira Napoleon Pekanbaru bread business strategy. Using qualitative research methods with discussion research. The SWOT analysis is used in this study to describe and choose the right strategy to maintain the existence of the business. In practice, the culinary business requires a capable strategy to be able to compete with similar businesses. The results of this study indicate that Nadhira Napoleon Pekanbaru has a number of appropriate business strategies to increase sales and overcome the competition. The main factor of this effort is to carry out promotions using social media or directly in creative and innovative ways to attract the attention of new customers and consumers, this is done in order to introduce and strengthen the Nadhira Napoleon Pekanbaru bakery brand.
\end{abstract}

Keyword : Business Strategy, SWOT Analysis, Competition.

\section{PENDAHULUAN}

Makanan adalah salah satu kebutuhan hidup manusia yang paling mendasar dan merupakan kebutuhan primer setiap manusia untuk mempertahankan hidupnya. Makanan selalu dibutuhkan oleh manusia untuk dikonsumsi setiap hari. Kemajuan teknologi dan informasi telah banyak mengubah pola hidup masyarakat, termasuk perubahan pola dalam mengkonsumsi makanan. Kini masyarakat cenderung memilih makanan instan dan siap saji, sehingga rata-rata konsumsi makanan di Indonesia tergolong tinggi.

Salah satu produk makanan yang umum dan cukup disukai oleh masyarakat adalah roti. Sekarang ini, roti telah banyak dinikmati oleh berbagai kalangan masyarakat. Biasanya 
roti dikonsumsi sebagai makanan pelengkap atau bahkan sebagai makanan pengganti. Roti memiliki ciri khas rasa yang berbeda dibanding dengan makanan yang lain. Rasa dan aroma yang khas pun memiliki cita rasa tersendiri yang membuat para penggemar makanan ini menjadi semakin tertarik untuk mengkonsumsinya.

Pekanbaru merupakan kota besar yang menjadi ibu kota bagi provinsi Riau dan sudah lama terkenal sebagai kota perdagangan dan pertambangan minyak bumi. Pekanbaru juga mempunyai banyak kuliner menarik yang tidak kalah dengan daerah lain. Banyak makanan khas Pekanbaru yang sangat menggoda. Perpaduan cita rasa yang baru dan unik didapat dari perpaduan budaya tradisionalnya, seperti Bolu Gulung Meranti, Ketan Talam Durian, Lempuk Durian, dan lain-lain. Jika singgah ke kota Pekanbaru, tidak lengkap rasanya jika tidak mencicipi kuliner khas setempat untuk menambah wawasan kuliner di seluruh Indonesia.

Nadhira Napoleon Pekanbaru, sebagai pusat oleh-oleh terbesar dan terlengkap di Pekanbaru, yang menyediakan berbagai macam oleh-oleh. Mulai dari cake, kue kering dan basah, keripik, hingga berbagai jenis minuman. Seperti Bolu Gulung Meranti, Ketan Talam Durian, Lempuk Durian, berbagai jenis keripik, Kopi Liberika, dan berbagai jenis minuman kekinian. Selain itu, juga banyak menjajarkan makanan khas Sumatera Utara dan Sekitarnya sebut saja Medan Napoleon dan Bolu Meranti yang terkenal itu. Nadhira Napoleon Pekanbaru memiliki tiga gerai toko, dimana gerai pertamanya terletak tidak jauh dari Bandara Sultan Syarif Kasim II Pekanbaru, gerai kedua terletak di Jl. Jendral Sudirman, dan gerai ketiganya terletak di di Jalan HR Soebrantas, Panam.

Melihat realita ini dari berbagai aspek dan latar belakang tersebut, maka penulis memilih Nadhira Napoleon Pekanbaru yang merupakan usaha pusat oleh-oleh Pekanbaru sebagai objek penelitian. Berdasarkan latar belakang masalah yang telah dikemukakan, maka dapat disajikan rumusan masalahnya adalah bagaimana keadaan lingkungan eksternal dan lingkungan internal yang memunculkan kekuatan (strength), kelemahan (weakness), peluang (opportunity), dan ancaman (threat) pada usaha roti Nadhira Napoleon Pekanbaru, serta strategi bisnis apakah yang paling tepat untuk mengembangkan perusahaan roti Nadhira Napoleon Pekanbaru guna memenangkan persaingan usaha bakery (perindustrian roti) dan pusat oleh-oleh, khususnya di kota Pekanbaru. Penelitian ini bertujuan untuk merancang strategi usaha roti di Nadhira Napoleon Pekanbaru. Sedangkan secara khusus penelitian ini bertujuan untuk mengidentifikasi kekuatan (strength), kelemahan (weakness), peluang (opportunity), dan ancaman (threat) yang terdapat pada usaha di perusahaan roti Nadhira Napoleon Pekanbaru, serta untuk merumuskan pemilihan strategi bisnis pada Nadhira Napoleon Pekanbaru.

\section{Strategi}

Menurut David (2011:18-19), strategi adalah sarana bersama dengan tujuan jangka panjang yang hendak dicapai. Strategi bisnis mencakup ekspansi georafis, diversifikasi, akusisi, pengembangan produk, penetrasi pasar, pengetatan, divestasi, likuidasi, dan usaha patungan atau joint venture. Strategi adalah aksi potensial yang membutuhkan keputusan manajemen puncak dan sumber daya perusahaan dalam jumlah besar. Jadi strategi adalah sebuah tindakan aksi atau kegiatan yang dilakukan oleh seseorang atau perusahaan untuk mencapai sasaran atau tujuan yang telah di tetapkan.

Sedangkan menurut Tjiptono (2006:3), istilah strategi berasal dari bahasa Yunani yaitu "strategia" yang artinya seni atau ilmu untuk menjadi seorang jendral. Strategi juga bisa diartikan suatu rencana untuk pembagian dan penggunaan kekuatan militer pada daerah daerah tertentu untuk mencapai tujuan tertentu. Dan menurut Pearce II dan Robinson (2008:2), strategi adalah rencana berskala besar, dengan orientasi masa depan, guna berinteraksi dengan kondisi persaingan untuk mencapai tujuan perusahaan

Dari beberapa pendapat tersebut, dapat disimpulkan bahwa pengertian dari strategi adalah sebuah tindakan proses perencanaan untuk mencapai tujuan yang telah di tetapkan, 
dengan melalukan hal-hal yang besifat terus menerus sesuai keputusan bersama dan berdasarkan sudut pandang kebutuhan pelanggan.

\section{Strategi Bisnis}

Tunggal (2004:37) menjelaskan bahwa strategi bisnis merupakan strategi yang harus di jadikan landasan berpikir utama dalam pembuatan strategi teknologi informasi karena dalam strategi tersebut di sebutkan visi dan misi perusahaan beserta target kinerja masing - masing fungsi dan struktur organisasi. Sedangkan Jatmiko (2004:135), menyatakan bahwa strategi bisnis merupakan serangkaian komitmen dan tindakan yang terintegrasi dan terkordinasi yang dirancang untuk menyediakan nilai bagi pelanggan dan dirancang untuk mendapatkan keunggulan kompetitif dengan mengeksplorasi kompetensi inti dari pasar produk tunggal atau produk individual dan spesifik.

Dari pendapat diatas, maka dapat disimpulkan bahwa pengertian strategi bisnis adalah serangkaian tindakan yang terintegrasi dan terkordinasi yang dijadikan landasan berpikir utama dalam pembuatan strategi untuk mendapatkan keunggulan kompetitif

\section{Analisis Lingkungan}

Analisis lingkungan dapat dibagi menjadi dua, yaitu lingkungan eksternal dan lingkungan internal. Menurut David (2010), analisis lingkungan eksternal adalah faktor-faktor yang ada dalam lingkungan eksternal, seperti persaingan antara perusahaan sejenis, potensi masuknya pesaing baru, potensi pengembangan produk pengganti, kekuatan tawar menawar dari pemasok, dan kekuatan tawar menawar dari konsumen. Sedangkan analisis lingkungan internal menurut David (2010:178-225) adalah audit internal yang membutuhkan pengumpulan dan pemaduan informasi mengenai manajemen pemasaran, keuangan/akuntansi, produksi/operasi, dan sumber daya manusia.

\section{Analisis SWOT}

Menurut Philip Kotler, analisis SWOT adalah evaluasi terhadap semua kekuatan, kelemahan, peluang, dan ancaman, yang terdapat pada individu atau organisasi. Sedangkan Pearce dan Robinson mengartikan analisis SWOT adalah bagian dari proses manajemen strategik perusahaan yang bertujuan untuk mengidentifikasi kekuatan dan kelemahan utama yang kemudian dibandingkan dengan peluang dan ancaman eksternal sebagai landasan untuk menghasilkan berbagai strategi alternatif.

Dan dari Fredy Rangkuti, definisi analisis SWOT adalah usaha yang dilakukan berdasarkan logika yang dapat memaksimalkan peluang dan kekuatan, dan pada saat yang sama dapat meminimalisir kelemahan dan ancaman. Analisis swot bertujuan untuk mengidentifikasi berbagai faktor secara sistematis untuk merumuskan strategi perusahaan.

Dari beberapa pendapat diatas dapat ditarik kesimpulan bahwa analisis SWOT didasarkan pada logika yang dapat memaksimalkan kekuatan (Strength) dan peluang (Opportunity), namun secara bersamaan dapat meminimalkan kelemahan (Weakness) dan ancaman (Threats) (Freddy Rangkuti, 2008:18).

\section{METODE PENELITIAN}

Ditinjau dari pendekatannya, penelitian ini digolongkan sebagai penelitian kualitatif. Penelitian kualitatif merupakan penelitian yang memiliki sasaran penelitian yang terbatas, tetapi dengan keterbatasan tersebut digali sebanyak mungkin data mengenai sasaran penelitian (Bungin, 2001:29).

Menurut tingkat eksplanasinya, penelitian ini dikategorikan sebagai penelitian deskriptif. Menurut Marzuki (2001:8) menyatakan bahwa penelitian deskriptif adalah penelitian yang dilakukan dengan melukiskan keadaan obyek atau persoalannya dan tidak dimaksudkan untuk mengambil atau menarik kesimpulan yang berlaku umum. Tujuan dari penelitian deskriptif adalah untuk membuat gambaran secara sistematis dan akurat mengenai fakta, sifat, dan hubungan antar aspek yang diteliti baik secara kualitatif maupun kuantitatif. Oleh karena 
itu, penelitian dilakukan dalam upaya mengidentifikasi faktor lingkungan perusahaan baik internal maupun eksternal.

Penelitian dilaksanakan pada perusahaan roti Nadhira Napoleon Pekanbaru. Nadhira Napoleon Pekanbaru merupakan usaha yang bergerak dibidang kuliner yang menjual roti dan oleh-oleh khas Pekanbaru. Jenis data yang digunakan dalam penelitian adalah data sekunder. Sumber data yang digunakan dalam penelitian ini berasal dari luar perusahaan (data eksternal). Menurut Marzuki (2000:12) terdapat tiga metode pengumpulan data, yaitu sensus, sampling, dan case study. Metode pengumpulan data yang akan dilakukan dalam penelitian ini adalah case study (studi kasus), yaitu metode pengumpulan data dengan mengambil beberapa elemen dari Nadhira Napoleon Pekanbaru yang kemudian masing-masing elemen diselidiki secara mendalam. Data-data yang diperoleh dari penelitian pada Nadhira Napoleon Pekanbaru difokuskan pada bidang manajemen strategi bisnis, khususnya formulasi dengan menggunakan alat-alat analisis yang telah tersedia yang kemudian diolah untuk di analisis dan didiskusikan secara bersama.

\section{HASIL DAN PEMBAHASAN \\ Profil Perusahaan}

Nadhira Napoleon Pekanbaru adalah pusat oleh-oleh terbesar dan terlengkap di Pekanbaru yang menjual berbagai macam oleh-oleh, mulai dari cake, kue kering dan basah, keripik, hingga berbagai jenis minuman. Selain itu di sini menyediakan makanan khas Sumatera Utara seperti Medan Napoleon dan Bolu Meranti.

Gerai pertamanya dibuka tidak jauh dari Bandara Sultan Syarif Kasim II Pekanbaru dengan tujuan awalnya membuat oleh-oleh khas Medan semakin dekat dengan peminatnya di Pekanbaru. Namun karena dekat dengan bandara dan banyak peminatnya, membuat bisnis ini berkembang pesat hingga akhirnya pada 21 Desember 2019 lalu, Nadhira Napoleon Pekanbaru kembali membuka gerainya yang kedua yang terletak di Jl. Jendral Sudirman, dan pada 3 April 2021, ditengah masa pandemi, Nadhira Napoleon Pekanbaru kembali membuka gerai ketiganya yang berlokasi di Jalan HR Soebrantas (Panam).

Nadhira Napoleon Pekanbaru juga mengakomodir banyak produk UMKM lokal lainnya. Mereka juga menjual berbagai macam produk makanan dan minuman dari ratusan pelaku usaha mikro kecil dan menengah (UMKM) yang menjadi mitra, seperti Ketan Talam Durian dan Lapis Ubi Durian.

\section{Analisis Lingkungan Eksternal}

1. Persaingan

Pada jenis industri oleh-oleh yang berada di Pekanbaru ini didapati persaingan yang mana persaingan tersebut berasal dari pesaing yang terlebih dahulu berada di Pekanbaru yaitu Rumah Kue Viera Pekanbaru. Rumah Kue Viera Pekanbaru ini juga memproduksi produk yang serupa dengan produk yang dihasilkan Nadhira Napoleon Pekanbaru, salah satu produk yang sama tersebut adalah Ketan Talam Durian. Sehingga bisa dikatakan dalam segi produk tentu saja mengalami persaingan yang cukup ketat.

2. Potensi Masuknya Pesaing Baru

Industri oleh-oleh dapat dikatakan memiliki potensi yang cukup besar, sehingga tidak hanya pesaing lama saja yang harus diperhatikan melainkan akan munculnya pesaing baru di bidang yang sama pula. Maka dari itu sebagai usaha lebih dulu didirikan, Nadhira Napoleon Pekanbaru harus berusaha memaksimalkan kinerja usaha yang dimiliki terlebih dahulu, baik itu dari segi pemasaran, produksi, pelayanan, serta target pasar yang telah ditentukan sejak awal

3. Produk Substitusi

Untuk produk pengganti atau substitusi, Nadhira Napoleon Pekanbaru dapat fokus menjual kembali produk pertama mereka, Medan Napoleon yang mana produk tersebut memiliki potensi dalam pengembangan Nadhira Napoleon Pekanbaru sehingga Nadhira Napoleon Pekanbaru meningkat cukup baik dan berhasil membuka gerai barunya.

4. Daya Tawar Pemasok 
Dari segi penawaran pemasok, suatu persaingan dari industri oleh-oleh di Pekanbaru terdapat sejumlah pemasok, tetapi hanya terdapat sedikit barang substitusi yang cukup bagus. Keberadaan pemasok bahan baku seperti telur, gula, dan tepung terigu mempunyai peranan penting dalam kegiatan produksi. Oleh sebab itu, Nadhira Napoleon Pekanbaru harus terus memantau serta mengendalikan persediaan bahan bakunya.

5. Daya Tawar Pembeli

Selain berdasarkan penawaran dari pihak pemasok, terdapat juga pihak lainnya yang berperan penting bagi usaha yaitu pihak pembeli. Nadhira Napoleon Pekanbaru harus dapat menawarkan produk yang memiliki kualitas dan variasi produk yang beraneka ragam serta harga yang terjangkau sehingga dapat dinikmati oleh berbagai kalangan konsumen.

\section{Analisis Lingkungan Internal}

1. Pemasaran

Menurut Kotler dan Lane (2007) dalam (Lukmandarru \& Istoto,2016), menyatakan bahwa pemasaran adalah suatu proses sosial yang di dalamnya terdapat individu dan kelompok yang mendapatkan apa yang mereka butuhkan serta inginkan dengan menciptakan, menawarkan, dan secara bebas menukarkan produk yang bernilai dengan pihak lain. Target pasar yang dimiliki Nadhira Napoleon Pekanbaru tertuju pada berbagai kalangan di masyarakat. Selain memasarkan produknya secara langsung di tokonya, Nadhira Napoleon Pekanbaru juga memasarkan produknya melalui media jejaring sosial, seperti Instagram, Facebook, dan aplikasi berbasis layanan transportasi seperti Gojek.

2. Keuangan

Pada bagian keuangan dijalankan oleh bagian divisi keuangan Nadhira Napoleon Pekanbaru. Dalam mengevaluasi kinerja bagian keuangan, Nadhira Napoleon Pekanbaru menggunakan cara audit yaitu melihat apakah ada selisih dalam saldo laporan keuangan. Selain itu terdapat juga laporan keuangan setiap bulan yang digunakan untuk melihat kinerja Nadhira Napoleon Pekanbaru pada setiap bulannya.

3. Fungsi Operasional

Dalam kegiatan operasionalnya, Nadhira Napoleon Pekanbaru menggunakan dua cara, yaitu memproduksi secara langsung dan menerima produk dari beberapa mitra lainnya. Teknologi yang digunakan oleh Nadhira Napoleon Pekanbaru adalah menggunakan komputer untuk meng-input data serta telepon yang digunakan untuk menerima pesanan konsumen.

4. Sumber Daya Manusia

Dalam hal rekruitman karyawan, Nadhira Napoleon Pekanbaru mengutamakan kemampuan dalam berbagai hal, baik itu kemampuan dalam pemasaran, memasak, maupun kemampuan lainnya yang berguna sehingga tidak menimbulkan kerugian bagi Nadhira Napoleon Pekanbaru.

\section{Analisis SWOT}

Menurut Freddy (2013), analisis SWOT adalah analisa yang didasarkan pada logika yang dapat memaksimalkan kekuatan (Strength) dan peluang (Opportunity), namun secara bersamaan dapat meminimalkan kelemahan (Weakness) dan ancaman (Threats).

Menurut Dj. Rusmawati (2017:918), Kekuatan (Strength) adalah semua potensi yang dimiliki perusahaan dalam mendukung proses pengembangan perusahaan, seperti kualitas sumber daya fasilitas-fasilitas perusahaan baik bagi SDM maupun bagi konsumen dan lainlain. Sedangkan, kelemahan (Weakness) adalah analisis kelemahan, dimana situasi dan kondisi yang merupakan kelemahan dari suatu perusahaan pada saat ini. Peluang (Opportunity) adalah faktor-faktor lingkungan luar atau ekternal yang positif, secara sederhana dapat diartikan sebagai setiap situasi lingkungan yang menguntungkan bagi suatu perusahaan atau satuan bisnis. Dan menurut Irawan (2014:569), ancaman (Threats) adalah tantangan yang diperlihatkan atau diragukan oleh suatu kecenderungan atau suatu 
perkembangan yang tidak menguntungkan dalam lingkungan yang akan menyebabkan kemerosotan kedudukan perusahaan.

Berdasarkan analisis SWOT pada Nadhira Napoleon Pekanbaru, maka strategi alternatif yang dapat dihasilkan adalah sebagai berikut.

1. Strategi SO (Strength - Opportunity)

Strategi ini menggunakan kekuatan yang dimiliki oleh usaha Nadhira Napoleon Pekanbaru agar dapat memanfaatkan peluang yang ada disekitarnya. Peluang yang dimaksudkan bisa berupa pengembangan pasar dengan memperluas pasar seperti membuka cabang baru di luar kota. Nadhira Napoleon Pekanbaru dapat menggunakan kekuatan yang dimilikinya dalam hal menentukan harga dengan cara membandingkan harga dengan pesaing.

2. Strategi WO (Weakness - Opportunity)

Strategi ini memiliki peran untuk mengatasi kelemahan yang dimiliki Nadhira Napoleon Pekanbaru melalui peluang yang ada. Kurangnya variasi produk oleh-oleh khas Pekanbaru menjadi kelemahan sekaligus peluang bagi Nadhira Napoleon Pekanbaru apabila dalam pihak Nadhira Napoleon Pekanbaru memiliki suatu invoasi yang berbeda dari pesaing-pesaingnya.

3. Strategi ST (Strength - Threats)

Strategi ini menggunakan kekuatan untuk mengatasi ancaman. Ancaman yang dimiliki oleh Nadhira Napoleon Pekanbaru adalah banyaknya pesaing dalam industri yang sama. Untuk mengatasi ancaman ini, Nadhira Napoleon Pekanbaru dapat menggunakan strategi peningkatan pangsa pasarnya baik dari segi produk maupun jasa yang dimilikinya. Dalam hal peningkatan pangsa pasarnya, Nadhira Napoleon Pekanbaru melibatkan hubungan baik antara Nadhira Napoleon Pekanbaru dengan konsumen, pemasok yang dimiliki serta mitra yang bekerja sama dengan Nadhira Napoleon Pekanbaru.

4. Strategi WT (Weakness - Threats)

Strategi ini meminimalkan kelemahan untuk menghindari ancaman. Jangkauan pasar Nadhira Napoleon Pekanbaru tidak tersedia di Pekanbaru bagian Timur (Rumbai dan sekitarnya), sehingga konsumen yang berada di daerah tersebut harus menempuh jarak yang cukup jauh untuk membeli produk Nadhira Napoleon Pekanbaru. Oleh sebab itu, Nadhira Napoleon Pekanbaru sebaiknya membuka cabang baru di daerah tersebut agar semakin banyak dikenal masyarakat dan dapat tetap dekat dengan konsumen.

\section{KESIMPULAN}

Kondisi lingkungan eksternal yang memengaruhi Nadhira Napoleon Pekanbaru adalah persaingan antar usaha sejenis yang cukup tinggi dan potensi masuknya pesaing baru cukup besar. Dalam potensi pengembangan produk pengganti, tidak menjadi ancaman besar bagi Nadhira Napoleon Pekanbaru karena produknya yaitu Medan Napoleon sudah memikat hati konsumen sejak awal Nadhira Napoleon Pekanbaru berdiri. Produk tersebut pula yang membuat Nadhira Napoleon Pekanbaru berkembang sehingga dapat membuka gerai keduanya. Daya tawar pemasok tidak terlalu berpengaruh, karena Nadhira Napoleon Pekanbaru mendapatkan harga yang cukup murah dari pihak pemasoknya. Untuk daya tawar konsumen juga tidak terlalu berpengaruh karena harga yang ditetapkan sudah cukup murah bagi konsumen dan cenderung sama dengan harga yang ditetapkan oleh pesaingnya.

Kondisi lingkungan internal dalam melakukan pemasaran, strategi yang digunakan oleh Nadhira Napoleon Pekanbaru dinilai sudah cukup bagus karena Nadhira Napoleon Pekanbaru menjual produknya secara langsung di toko dan menjualkannya secara online melalui media sosial serta platform seperti Gojek. Pengelolaan keuangan di Nadhira Napoleon Pekanbaru sangat baik karena setiap bulan terdapat evaluasi laporan keuangan. Dalam sistem operasional Nadhira Napoleon Pekanbaru memproduksi produknya secara langsung dan menerima produk dari beberapa mitra lainnya. Dalam perekrutan karyawan, Nadhira Napoleon Pekanbaru biasanya mengiklankan di koran dan di media sosial seperti Instagram 
dan Facebook, yang mana mereka mengutamakan kemampuan dalam berbagai hal terutama memasak.

Wilayah pendistribusian Nadhira Napoleon Pekanbaru masih kurang dan dinilai belum menjangkau seluruh wilayah Pekanbaru, khususnya dibagian Pekanbaru Timur (Rumbai dan sekitarnya). Sehingga Nadhira Napoleon Pekanbaru perlu membuka cabang baru di kawasan daerah tersebut, agar semakin dekat dengan konsumennya dan dapat meningkatkan pangsa pasar mereka.

Berdasarkan kesimpulan yang dijelaskan, maka saran yang akan diberikan oleh peneliti kepada Nadhira Napoleon Pekanbaru adalah :

1. Nadhira Napoleon Pekanbaru harus mencari tempat-tempat yang strategis, khususnya wilayah Pekanbaru Timur untuk membuka cabang baru guna perluasan wilayah distribusi.

2. Nadhira Napoleon Pekanbaru dapat meningkatkan promosi penjualan dengan mengajak selebgram untuk mengiklankan produknya.

3. Nadhira Napoleon Pekanbaru dapat menciptakan inovasi baru pada produknya agar dapat menarik lebih banyak konsumen.

4. Nadhira Napoleon Pekanbaru harus memberkan pelatihan khusus kepada karyawan untuk meningkatkan kinerja karyawan dan usahanya.

\section{DAFTAR PUSTAKA}

Faruq, Mochamad Ammar dan Indrianawati Usman. 2014. Penyusunan Strategi Bisnis dan Strategi Operasi Usaha Kecil dan Menengah pada Perusahaan Konveksi Scissors di Surabaya. Jurnal Manajemen Teori dan Terapan: Tahun 7, No. 3

Gunawan, Cinthya Elika Putri. 2017. Analisis Strategi Bisnis pada PT. Omega Internusa Sidoarjo. AGORA: Vol. 5, No. 1.

Http://library.binus.ac.id/eColls/eThesisdoc/Bab2/2013-1-00190-MN\%20Bab2001.pdf

Kirana, Ade. Nadhira Napoleon, Pusat Oleh-Oleh Terbesar di Pekanbaru. Info PKU, 2020. Diakses pada 17 Juli 2021, dari https://www.google.com/amp/s/infopku.com/nadhiranapoleon-pusat-oleh-oleh-terbesar-di-pekanbaru/33071/\%3famp

Mimi, dan Rico. Tetap Eksis di Tengah Pandemi, Nadhira Napoleon Kini Buka Cabang Ketiga di Pekanbaru. Hallo Riau, 2021. Diakses pada 17 Juli 2021, dari https://m.halloriau.com/read-144951-2021-04-04-tetap-eksis-di-tengah-pandeminadhira-napoleon-kini-buka-cabang-ketiga-di-pekanbaru.html 